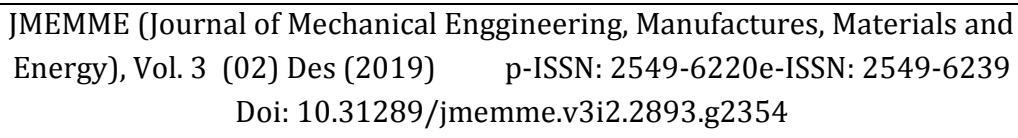

Available online http://ojs.uma.ac.id/index.php/jmemme

\title{
RANCANG BANGUN ALAT PENGHANCUR SAMPAH ORGANIK SKALA RUMAH TANGGA
}

\author{
Awang Surya*, Firmansyah Azharul, Wilarso \\ Program Studi Teknik Mesin, Sekolah Tinggi Teknologi Muhammadiyah Cileungsi \\ Diterima: 16-09-2019 ; Disetujui: 13-11-2019 ; Diterbitkan: 30-12-2019 \\ *Corresponding author: awang_surya@yahoo.com
}

\begin{abstract}
Abstrak
Di setiap kota atau perumahan masalah sampah menjadi urusan serius. Dampak buruk dari sampah ialah polusi udara, pencemaran tanah dan air, dan gangguan kesehatan. Salah satu sumber sampah adalah sampah yang berasal dari rumah tangga. Untuk sampah non organik, secara umum sebagian masyarakat sudah menangani dengan cara dipungut oleh para pemulung atau dikumpulkan oleh pemilik rumah untuk kemudian dijual kepada para pengepul. Sementara masalah ada pada sampah organik ialah sampah ini perlu dihancurkan terlebih dahulu untuk bisa dimanfaatkan sebagai kompos atau sumber energi lain dalam bentuk biogas. Tujuan penelitian ini ialah untuk merancang dan membangun alat penghancur sampah organik untuk skala rumah tangga dan industri kecil. Metode yang telah dilakukan ini menghasilkan prototipe alat penghancur sampah organik yang baik yang ditinjau dari sisi dimensi dan daya listrik sehingga memungkinkan dipakai di setiap rumah tangga. Ukuran alat yang dibuat adalah: tinggi $37 \mathrm{~cm}$, lebar $20 \mathrm{~cm}$, panjang $23 \mathrm{~cm}$. Berat total $5 \mathrm{Kg}$. Alat ini juga bisa dioperasikan dengan menggunakan sumber listrik dari rumah tipe RS karena menggunakan motor listrik 400 Watt. Kapasitas pencacahan dari alat yang dihasilkan dari penelitian ini adalah10 kg/jam.
\end{abstract}

Kata Kunci: Penghancur Sampah, Sampah organik, skala rumah tangga, biogas

\begin{abstract}
In every city or housing, the waste problem is a serious matter. The adverse effects of waste in the form of air pollution, soil and water pollution to health problems. One source of waste is households. For nonorganic waste, in general some people have handled it by collecting and collecting it by the house owners and then selling it to collectors. The problem is with organic waste. Organic waste needs to be destroyed to be used as compost or an energy source in the form of biogas. This method has produced a prototype of an organic waste crusher that is good in terms of dimensions and allows electrical power to be used in every Indonesian family home. The size of the equipment made is: Height $37 \mathrm{~cm}$, Width $20 \mathrm{~cm}$, Length $23 \mathrm{~cm}$. Total weight of $5 \mathrm{~kg}$. This tool can also be operated by using a power source from a hospital type house because it uses a 400 Watt electric motor. Enumeration capacity of the tools produced from this study is $10 \mathrm{~kg} / \mathrm{hour}$
\end{abstract}

Keywords: Garbage Crusher, Organic Waste, home scale, biogas

How to Cite: Surya, A., 2019, Rancang Bangun Alat Penghancur Sampah Organik Skala Rumah Tangga, JMEMME (Journal of Mechanical Enggineering, Manufactures, Materials and Energy), 3(02): 92-99 


\section{PENDAHULUAN}

Pertumbuhan penduduk yang cukup tinggi yang diikuti dengan tumbuhnya wilayah-wilayah pemukiman baru telah menimbulkan berbagai masalah. Salah satu masalah yang perlu mendapat perhatian adalah sampah. Saat ini sampah telah menjadi masalah nasional. Hampir di seluruh kota di Indonesia mengalami masalah dengan sampah. Pemerintah daerah mengalokasikan biaya yang tidak sedikit untuk menangani sampah.

Secara umum sampah bisa dipilah menjadi sampah organik dan sampah anorganik. Sampah organik atau sampah basah ialah sampah yang berasal dari makhluk hidup, seperti dedaunan, sisa makanan dan sampah dapur. Sampah jenis ini sangat mudah terurai secara alami (degradable). Sedangkan sampah anorganik adalah sampah yang tidak dapat terurai (undegradable), seperti karet, plastik, kaleng dan logam [1].

Pengelolaan sampah yang tidak tepat akan menimbulkan dampak negatif. Dampak buruk itu bisa pada kesehatan, lingkungan dan sosial ekonomi. Sampah bisa menjadi tempat pembiakan lalat dan disenangi tikus sehingga mendorong penularan infeksi. Sampah menurunkan kualitas lingkungan, estetika terganggu karena bau dan berserakan. Pembuangan sampah ke badan air mengakibatkan banjir dan meningkatkan biaya pengelolaan air. Sampah berdampak pula pada perkembangan pariwisata. Persoalan sampah dapat menghambat perkembangan otonomi daerah dan mengurangi arus investor [2].
Tindakan memusnahkan sampah dengan membakar juga bukan tanpa masalah. Pembakaran sampah rumah tangga menghasilkan gas buang yang mempunyai kontribusi terhadap terbentuknya gas rumah kaca yang disebabkan karena emisi gas karbon dioksida (CO2) dan N20 yang terlepas ke atmosfer. Selain itu polutan lain dapat terbentuk pada proses pembakaran antara lain logam berat, abu terbang, abu sisa pembakaran, dioksin dan furan, $\mathrm{HCl}$, HF, SO2 dan CxHy. Produk hasil pembakaran yang berpotensi mencemari lingkungan perlu dikontrol sampaimencapai ambang batas yang diperbolehkan [3]. Sumber utama sampah di Indonesia adalah sampah rumah tangga, yang sebagian besar (5070\%) merupakan sampah yang mudah membusuk berasal dari sisa makanan, kulit buah, sayuran, dan lain sebagainya. Tetapi apabila sampah rumah tangga dikelola dengan baik, pengelolaan sampah memiliki kemungkinan potensial tidak hanya mengurangi dampak lingkungan dari sampah itu sendiri, tetapi bisa juga melalui peningkatan pemanfaatan limbah berkontribusi untuk pengurangan emisi sektor selain sampah [4].

Di Indonesia menurut penelitian Pusat Lingkungan Hidup ITB, rata-rata rumah tangga menghasilkan 2,5 kg sampah per hari.("PENGELOLAAN SAMPAH DI KOTA SEMARANG UNTUK MENUJU KOTA BERSIH," 2014) Sebagian besar sampah rumah tangga di Indonesia kurang dimanfaatkan dan cenderung diangkut ke Tempat Pembuangan Sementara (TPS) dan Tempat Pembuangan Akhir (TPA). Hanya 
Surya, A., Rancang Bangun Alat Penghancur Sampah Organik Skala ...

sebagian kecil dari sampah rumah tangga yang dikonversi menjadi komoditas yang memiliki nilai ekonomi, data dari Kementrian Lingkungan Hidup menyebutkan hanya 7,15 \% dari sampah yang terkumpul dikonversi menjadi pupuk.

Pemanfaatan sampah yang sudah umum dilakukan oleh masyarakat sering kali hanya pada sampah non organik. Sebagian anggota masyarakat sudah biasa mengumpulkan sampah plastik, logam dan kertas untuk dijual kepada pengepul. Sementara untuk sampah organik pemanfaatannya masih rendah. Akibatnya, sampah organik hanya ditumpuk dan sering kali menimbulkan masalah.

Rendahnya pemanfaatan sampah organik untuk komoditas yang punya nilai ekonomi ini disebabkan belum adanya alat penghancur sampah organik dalam skala kecil yang bisa diaplikasikan di setiap rumah. Alat-alat penghancur sampah organik yang ada di pasaran berskala besar, sehingga hanya bisa dioperasikan oleh perusahaan yang bergerak dalam bidang pemanfaatan sampah atau oleh pemerintahan.

Memperhatikan hal di atas, maka diperlukan sebuah penelitian untuk merancang bangun alat penghancur sampah organik. Alat ini diharapkan secara ukuran bisa ditempatkan di rumah dengan mudah dan biaya yang murah.

1.1. Sampah.

Organisasi Kesehatan Dunia (World Health Organization) memberikan definisi bahwa sampah adalah sesuatu yang tidak digunakan, tidak dipakai, tidak disenangi atau sesuatu yang dibuang yang berasal dari kegiatan manusia dan tidak terjadi dengan sendirinya. Sedangkan menurut Undang-Undang Republik Indonesia nomor 18 Tahun 2008 tentang Pengelolaan Sampah dijelaskan bahwa sampah adalah sisa kegiatan sehari manusia dan atau proses alam yang berbentuk padat [5].

Jenis sampah yang masih bisa diolah atau didaur ulang salah satunya adalah sampah organik. Sayangnya, sebagian besar sampah organik yang tidak ditangani dengan tepat. Akibatnya di mana-mana sampah organik membawa dampak buruk. Saat ini sampah organik telah menjadi masalah yang cukup serius bagi pencemaran khususnya bagi pencemaran lingkungan. Timbunan sampah organik dengan cepat akan membusuk dan menimbulkan bau busuk. Perkiraan umum volume produksi sampah organik di negara kita rata-rata sekitar $0,5 \mathrm{~kg} /$ kapita /hari.

1.2. Pemanfaatan Sampah Organik.

Sampah organik memiliki kemampuan untuk mendekomposisi sehingga menjadi senyawa yang lebih sederhana karena adanya faktor lingkungan seperti kelembaban, iklim, suhu, tekanan, keseimbangan nutrien (rasio C/N), derajat keasaman, dan homogenitas campuran. Jumlah presentase sampah organik lebih besar dibandingkan sampah anorganik, 65\%95\% biasanya terdiri dari sampah organik tergantung jenis kota [6].

Selain masalah yang ditimbulkan, sebenarnya sampah organik memiliki manfaat. Dengan penanganan yang tepat sampah organik bisa digunakan untuk 
kebutuhan rumahtangga, pertanian, bahkan bisa digunakan sebagai hiasan. Secara garis besar, beberapa pemanfaatan sampah organik yang sudah dikenal adalah sebagai berikut:

1) Kompos

Kompos adalah salah satu pupuk organik buatan manusia yang dibuat dari proses pembusukan sisa-sisa bahan organik (tanaman maupun hewan). Proses pengomposan dapat berlangsung secara aerobik dan anaerobik yang saling menunjang pada kondisi lingkungan tertentu. Proses pembuatan kompos sebenarnya meniru proses terbentuknya humus di alam, namun dengan cara merekayasa kondisi lingkungan kompos dapat dipercepat proses pembuatannya, yaitu hanya dalam jangka waktu 30-90 hari. Waktu ini melebihi kecepatan terbentuknya humus secara alami.

2) Pupuk Organik Cair

Pupuk organik cair adalah larutan hasil dari pembusukan bahan-bahan organik yang berasal dari sisa tanaman dan kotoran hewan, dengan kandungan unsur hara yang majemuk. Bahan-bahan untuk membuatnya inilah yang membedakan pupuk organik dan anorganik. Hasil uji komposisi kandungan unsur hara pada pupuk anorganik biasanya lebih lengkap dan terukur dibandingkan dengan pupuk organik cair.

3) Unsur tambahan pakan ternak

Beberapa penelitian menunjukkan bahwa sampah organik bisa diolah menjadi unsur tambahan pakan ternak. Sampah yang menjadi bahan pakan adalah sisa-sisa sayuran, daging, sisa buah-buahan dan juga sisa buangan pabrik tahu dan tempe. Bahan-bahan sisa tersebut difermentasi oleh mikroba Niitrogen Phosphate Recovery Consentred Feed Product Developpment Organism (NOPCO). Dalam proses fermentasinya dibutuhkan waktu sekitar 4- 8 hari.

4) Biogas

Sampah-sampah organik merupakan sumber penting dalam membuat biogas. Dari sampah organik bisa dihasilkan gas yang mudah terbakar. Biogas timbul dari hasil proses fermentasi sampah organik rumah tangga oleh bakteri anaerob yang hidup tanpa udara. Biogas antara lain terdiri dari: Metana sebesar 60\%, karbondioksida 38\%, dan 2\%nya 02, $\mathrm{H} 2$, N2 dan H2S. Biogas ini dapat terbakar seperti gas elpiji, bahkan dalam skala besar bisa digunakan sebagai pembangkit tenaga listrik.

5) Kerajinan Tangan

Pemanfaatan sampah organik sebagai kerajinan tangan banyak ragamnya. Hampir semua sampah organik basah seperti kulit buah, daundaunan dan sampah organik kering seperti kulit telur, tempurung kelapa dan lain-lain semua bisa dimanfaatkan oleh para perajin untuk membuat kerajinan tangan. Tentu saja semua melaui proses pendahuluan sebelum digunakan.

1.3. Penghancuran Sampah Organik.

Penghancuran atau pencacahan sampah organik menjadi proses penting dalam pembuatan kompos atau untuk biogas. Pencacahan akan memperluas sebaran mikroorganisme pada sampah organik sehingga lebih mudah dan lebih cepat proses pelapukannya. Proses 
Surya, A., Rancang Bangun Alat Penghancur Sampah Organik Skala ...

mencacah sampah/bahan organik seperti daun-daun basah, rantingranting kecil, sampah rumah tangga, dan lain-lain dapat dilakukan secara manual, tetapi untuk mempercepat dan mempermudah proses pencacahan dibutuhkan mesin [7].

Kenyataan di lapangan menunjukkan sampah organik rumah tangga adalah sisa sayuran, buahbuahan, daun-daunan dan lain-lain yang berukuran cukup besar. Sampah-sampah tersebut perlu diproses selanjutnya agar memiliki ukuran yang lebih kecil. Alat penghancur sampah akan membuat sampah menjadi berukuran lebih kecil. Komponen utama alat ini adalah pisau potong yang berputar sehingga memotong sampah-sampah menjadi lebih kecil.

\section{METODE}

Pada metode ini ada beberapa tahapan yang dilakukan yaitu sebagai berikut:

Studi Pendahuluan

Pada tahap ini, kegiatan penelitian akan difokuskan pada kegiatan studi literatur yang berkaitan dengan pengolahan sampah organik, terutama alat-alat penghancur sampah organik. Studi literatur dilakukan oleh peneliti dengan mengumpulkan sejumlah buku dan naskah dari laman web. Hal ini dilakukan dengan tujuan untuk mengungkapkan berbagai teori-teori yang relevan dengan permasalahan yang sedang diteliti sebagai bahan rujukan dalam pembahasan hasil penelitian. Selanjutnya dilakukan kajian hasil penelitian terdahulu yang berikaitan dengan alat penghancur sampah organik dan juga alat-alat penghancur sampah organik yang sudah ada di pasaran. Hal ini untuk mendapatkan kelebihan dan kekurangan alat-alat penghancur sampah organik yang sudah ada.

Perencanaan dan Pengembangan Alat

Berdasarkan deskripsi dan analisis temuan yang didapat, selanjutnya disusun langkah-langkahpengembangan sebagai berikut:

a) Merumuskan rencana pengembangan yang mencakup identifikasi yang berkaitan dengan pengembangan alat penghancur sampah organik, menentukan tujuan yang akan dicapai padasetiap tahapan pengembangan.

b) Pembuatan alat penghancur sampah organik yang bisa dengan mudah dioperasikan di rumahrumah dengan mempertimbangkan aspek ergonomis dan ekonomi.

Uji Coba dan Perbaikan

Setelah pengembangan alat rampung, maka selanjutnya dilakukan tahapan berikut:

a) Uji coba awal alat penghancur sampah organik. Tujuan langkah ini adalah untuk mengetahui apakah alat yang dikembangkan dapat berfungsi sebagaimana mestinya. Perbaikan terhadap kekurangan dari alat yang dikembangkan dengan memperhatikan hasil dari uji coba awal.

b) Perbaikan ini sangat mungkin dilakukan beberapa kali sesuai dengan hasil yang ditunjukkan dalam ujicoba, sehingga diperoleh alat penghancur sampah organik 
skala rumah tangga yang lebih sempurna.

\section{HASIL DAN PEMBAHASAN}

a. Pendekatan Perencanaan.

Awal perencanaan mesin penghancur sampah organik skala rumah tangga ini untuk menciptakan inovasi teknologi tepat guna. Mesin pencacah sampah ini dirancang untuk diaplikasikan di lingkungan rumah tangga. Selanjutnya, beberapa batasan perancangan dapat dilihat dibawah ini.

b. Klarifikasi Tujuan:

Setelah diadakan brainstorming dengan tim didapatkan beberapa tujuan dari perancangan yang digambarkan di dalam Objectives Tree pada gambar 1 .

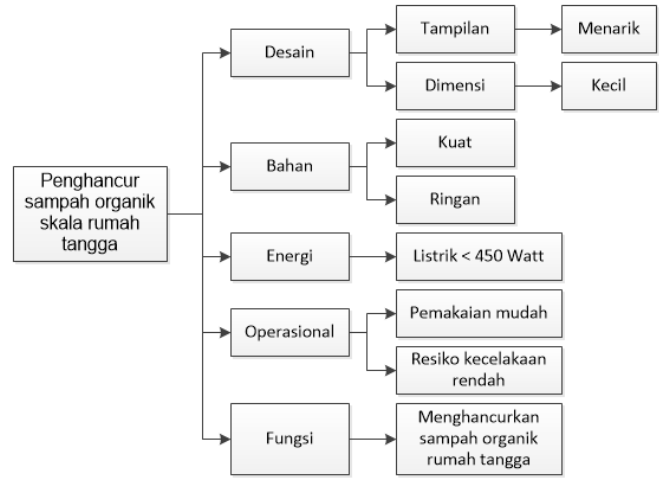

Gambar 1. Alir proses perancangan penghancur sampah organic

\section{c. Penetapan Fungsi}

Beberapa fungsi dari alat yang dirancang secara sederhana digambarkan di dalam blok diagram seperti gambar 2 .

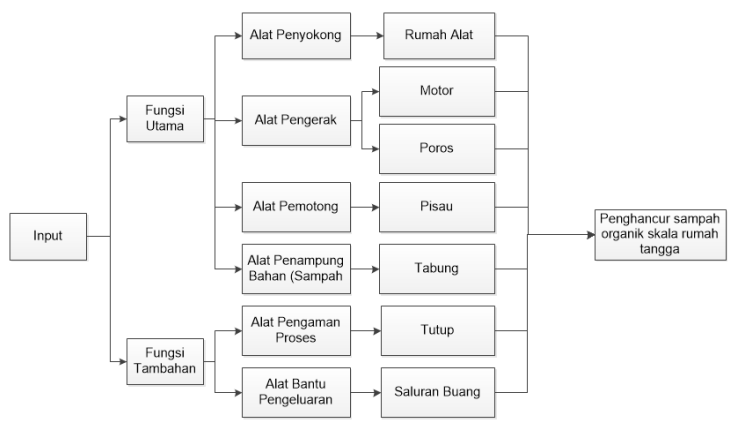

Gambar 2. Alir fungsi penghancur sampah organic

d. Data Teknis.

Alat yang dibuat, dirancang sedemikian rupa agar mudah ditempatkan di dapur atau ruangan lain yang memungkinkan. Untuk itu dimensi alat harus kecil agar tidak menyita tempat. Juga alat harus bisa dioperasikan di rumah tipe Rumah Sederhana (RS) yang menggunakan daya listrik kecil. Karena alat terutama tabung akan bersentuhan dengan bahan yang memungkinkan menyebabkan korosi maka dipilih bahan yang tahan korosi. Data alat yang dibuat adalah sebagai berikut:

- Tinggi : $37 \mathrm{~cm}$

- Lebar (kiri ke kanan) : $20 \mathrm{~cm}$

- Panjang (depan ke belakang): 23 $\mathrm{cm}$

- Motor listrik : 400 Watt

- Material tabung: Stainless steel 304 dengan ketebalan 1,0 mm

- Material pisau pencacah: SS 400 dengan ketebalan 1,0 mm

- Berat alat total : $5 \mathrm{Kg}$

e. Daya Tampung Alat.

Daya tampung alat adalah volume maksimal sampah organik yang bisa diproses pada alat pada waktu yang 
Surya, A., Rancang Bangun Alat Penghancur Sampah Organik Skala ...

sama. Dalam hal ini daya tampung ditentukan dari volume tabung penampung sampah organik yang akan dicacah. Volume tabung dapat dihitung dengan menggunakan persamaan 1 .

$$
V=\pi \cdot r^{2}
$$

Dimana:

$$
\begin{aligned}
& \mathrm{r}=\text { jari-jari tabung }(\mathrm{mm}) \\
& \mathrm{t}=\text { tinggi tabung }
\end{aligned}
$$

Data ukuran tabung penampung sampah adalah sebagai berikut:

- Tinggi tabung : $170 \mathrm{~mm}$

- Jari - Jari tabung : $80 \mathrm{~mm}$

Maka di dapat volume tabung / silinder:

$$
\begin{gathered}
V=\pi \cdot r^{2} \cdot t \\
V=\pi \cdot(80)^{2} \cdot 170 \\
V=3.416 .320 \mathrm{~mm}^{3}
\end{gathered}
$$

Karena di dalam tabung penampung sampah juga terdapat rangkaian pisau pencacah, maka daya tampung silinder atau tabung penampung sampah menjadi lebih kecil. Sehingga daya tampungnya adalah kurang lebih 75\% dari volume tabung, yaitu sebesar $2.562 .240 \mathrm{~mm}^{3}$ atau sekitar $2.562 \mathrm{~cm}^{3}$ atau kurang lebih setara 2,6 liter.

\section{f. Kapasitas Alat}

Kapasitas alat dihitung dengan menggunakan acuan persamaan 2 .

$$
C=(W / t) \times 3600
$$

Dimana:

C : kapasitas alat $(\mathrm{Kg} / \mathrm{jam})$

W : bobot bahan yang dicacah $(\mathrm{Kg})$ t : waktu yang dibutuhkan untuk mencacah (detik)

Dalam penelitian telah dilakukan percobaan dengan menggunakan campuran beberapa jenis sampah organik rumah tangga yaitu sisa sayur dan kulit buah. Berat sampah yang dicacah adalah 0,5 Kg. Diketahui untuk mencacah bahan tersebut sampai menjadi campuran menyerupai bubur, dibutuhkan waktu rata-rata 3 menit atau 180 detik. Maka kapasitas alat yang dibuat adalah sebagai berikut:

$$
\begin{gathered}
C=(0.5 / 180) \times 3600 \\
C=10 \mathrm{~kg} / \mathrm{jam}
\end{gathered}
$$

\section{KESIMPULAN}

Desain alat penghancur sampah organik dirancang dengan memperhatikan faktor kemudahan operasional, kekuatan, keamanan dan kenyaman pengguna. Ukuran tinggi alat maksimal $37 \mathrm{~cm}$. Bahan yang digunakan pada silinder pencacahan ialah dari bahan baja tahan karat (stainless steel). Motor listrik yang digunakan berdaya 400 Watt. Volume alat pencacah sampah organik ini adalah lebih kurang 2,6 liter dengan kapasitas pencacahan alat yang dibuat adalah sebesar $10 \mathrm{~kg} / \mathrm{jam}$.

\section{REFERENCES}

[1] I. Sundarta, A. Sari and H. P. Wibowo, "PENGELOLAAN LIMBAH ORGANIK MENJADI KOMPOS MELALUI PEMBUATAN TONG 
SUPER," Jurnal Pengabdian Pada Masyarakat, 2018.

[2] S. A. Mulasari, A. H. Husodo and N. Muhadjir, "Kebijakan Pemerintah dalam Pengelolaan Sampah Domestik," National Public Health Journal, 2014.

[3] E. Nuryono, "Perancangan Sistem Pemilahan , Pengeringan dan Pembakaran Sampah Organik Rumah Tangga," Indonesian Green Technology Journal, 2013.

[4] R. Windraswara and D. A. Prihastuti, "ANALISIS POTENSI REDUKSI SAMPAH RUMAH TANGGA UNTUK PENINGKATAN KUALITAS KESEHATAN LINGKUNGAN," Unnes Journal of Public Health, 2017.

[5] N. Marliani, "Pemanfaatan Limbah Rumah Tangga ( Sampah Anorganik ) Sebagai Bentuk Implementasi," Jurnal Formatif, vol. 4, no. 2, p. 124-132, 2014.

[6] D. Indrawati, B. Iswanto and K. A. Umam, "PENGARUH RESIRKULASI LEACHATE PADA PROSES DEKOMPOSISI SAMPAH ORGANIK SECARA ANAEROB," INDONESIAN JOURNAL OF URBAN AND ENVIRONMENTAL TECHNOLOGY, 2016.

[7] I. A. Hendaryanto, "Pembuatan Mesin Pencacah Sampah Organik Untuk Swadaya Pupuk di Desa Tancep Kecamatan Ngawen Kabupaten Gunungkidul," Jurnal Pengabdian Dan Pengembangan Masyarakat, 2018. 